\title{
Soil porosity changes in orchards with subsurface irrigation: quantification and interpretation
}

\author{
Rosa M. Poch, Miquel Pascual, Josep M. Villar, Josep Rufat
}

Rosa M. Poch

rosa.poch@macs.udl.cat

\section{Josep M. Villar}

Departament de Medi Ambient i Ciències del Sòl. Universitat de Lleida. Av. Rovira Roure,

191 E-25198 Lleida, Spain.

\section{Miquel Pascual}

Departament d'Hortofruticultura, Botànica i Jardineria. Universitat de Lleida. Av. Rovira Roure, 191 E-25198 Lleida, Spain.

\section{Josep Rufat}

Programa d'Ús Eficient de l'Aigua. Institut de Recerca i Tecnologia Agroalimentàries (IRTA). Parc Científic i Tecnològic Agroalimentari de Lleida. Parc de Gardeny - Edifici Fruitcentre. E-25003 Lleida, Spain.

BOL. SOC. GEOL. MEX. 2019

VOL. 71 NO. 1

P. $1-10$

http://dx.doi.org/10.18268/BSGM2019v71nlal

\begin{abstract}
In order to assess the irrigation efficiency under water-limiting conditions, four different treatments of subsurface irrigation of peach trees in a semi-arid Mediterranean climate near Lleida (NE Iberian Peninsula) were tested. The treatments included pressurized air injection, deficit irrigation, full irrigation (as control) and an addition of rice husk around the pipe to improve porosity. Because the latter treatment improved physical conditions and resulted in better tree growth, a micromorphological study was conducted in order to understand the reason for this behaviour. The experiment was carried out in a commercial peach orchard (Prunus persica L.). The soil was a Xeric Torriorthent, with a loam texture, affected by salinity and with low organic matter content. One undisturbed block (30 $\mathrm{cm}$ each side) was taken from each treatment, and two vertical thin sections, $5 \times 13 \mathrm{~cm}$, including the subsurface pipe, were made. A fluorescent dye was added to the polyester resin to obtain UV light images of the porosity. The pore parameters and the pore size distribution were obtained for each treatment. Strong changes in the pore types of the four treatments are evident in the thin sections. Full and deficit irrigation treatments are characterised by a weakly developed subangular blocky structure, with a vesicular intra-aggregate structure. Deficit irrigation with air injection produced, in its upper part, a structure similar to the full and deficit irrigation treatments. In the surroundings and below the pipe, where the effect of pressurized air was higher, the soil structure is apedal, with vesicles (bubbles), 200-500 $\mu \mathrm{m}$ in size. Porosity of the soil modified with rice husk is greater than that of the other three treatments: the $15-30 \mu \mathrm{m}$ porosity fraction is double, and the larger fractions three times that of the other treatments. It contains many oval excrements of mites (probably Oribatidae), $50-100 \mu \mathrm{m}$ in size, associated with moderately decomposed rice husk tissues. We conclude that the modifications around the irrigation pipes that promoted faunal activity are very effective in conveying water to the soil in comparison to that of pressurized air, which only increases vesicular (non connected) porosity.
\end{abstract}

Keywords: faunal activity, subsurface irrigation, micromorphology, pore size analyses, organic amendments, Ebro Valley.

\section{RESUMEN}

Para evaluar la eficiencia de riego en condiciones de limitación de agua, se ensayaron cuatro tratamientos diferentes de riego subsuperficial en melocotoneros (Prunus persica L.) en un clima mediterráneo semiárido cerca de Lleida (NE Península Ibérica). Los tratamientos consistieron en inyección de aire presurizado, irrigación deficitaria, irrigación completa (control) y una adición de cascarilla de arroz alrededor de la tubería para mejorar la porosidad. Debido a que el último tratamiento mejoró las condiciones fisicas y mejoró el crecimiento de los árboles, se realizó un estudio micromorfológico para comprender este comportamiento. El suelo fue un Xeric Torriorthent, con textura franca, afectado por salinidad y con un bajo contenido de materia orgánica. Se tomó un bloque no perturbado (30 cm de lado) de cada tratamiento, y se hicieron dos secciones delgadas verticales, $5 \times 13 \mathrm{~cm}$, incluyendo el tubo subterráneo. Se añadió un colorante fluorescente a la resina de poliéster para obtener imágenes UV de la porosidad. Se caracterizó la porosidad y se obtuvo la distribución del tamaño de poro para cada tratamiento. Los tipos de poros de los cuatro tratamientos mostraron diferencias evidentes en las secciones delgadas. Los tratamientos de riego completos y con déficit se caracterizan por una estructura de bloques subangulares poco desarrollada y una estructura intragregados vesicular. El riego deficitario con inyección de aire produce, en su parte superior, una estructura similar a las de riego completo y con déficit. En el entorno y por debajo de la tubería, donde el efecto del aire presurizado fue mayor, la estructura es apedial, con vesículas (burbujas), de 200 - 500 um de tamaño. La porosidad del suelo con cascarilla de arroz es el doble que los otros tres tratamientos. La fracción de 15 - 30 um se duplica, mientras que las fracciones mayores triplican las del resto de los tratamientos. Contiene muchos excrementos ovales de ácaros (probablemente Oribatidae), de $50-$ $100 \mu \mathrm{m}$ de tamaño, asociados a tejidos de cascarilla de arroz medianamente descompuestos. Podemos concluir que las enmiendas alrededor de las tuberías de riego que promueven la actividad faunística son muy efectivas para transportar agua al suelo, opuesto al aire presurizado que sólo aumenta la porosidad vesicular (no conectada).

Palabras clave: actividad de la fauna, riego subsuperficial, micromorfología, análisis de tamaño de poro, enmiendas orgánicas, Valle del Ebro. 


\section{Introduction}

In dry Mediterranean areas as well as in many arid and semi-arid areas in the world, irrigation is the only land management practice that ensures biomass production. Frequently, this is only possible after a careful irrigation strategy and design, since lack of water or low quality soil or water in these areas prevents sustainable and efficient use of water.

A higher irrigation efficiency has been promoted in recent years in the Ebro Valley (NE Iberian Peninsula) by government policies and water district authorities. The Ebro Valley is an area with more than $5 \times 10^{5}$ ha being irrigated with water of variable quality from the Ebro river and its tributaries as well as subsurface water coming from reservoirs in the Pyrenees. Many of the soils are saline or sodic and have low organic matter $(\mathrm{OM})$ contents. In addition, the predictions of climate change in the area indicate marked increases in evapotranspiration that imply greater irrigation needs. Fruit production is expanding in the Mediterranean Basin, sometimes at the expense of marginal land transformation. As a result of less available water and greater irrigation needs, irrigation management practices need to be optimised such as by using subsurface drip irrigation.

Mulching techniques have arisen to address these limitations. Kumar et al. (1985) and more recent studies (e.g., Kar and Kumar, 2007; Diana et al., 2008; Mubarak et al., 2009; Nwite et al., 2011) reported positive effects of organic by-products amendments on soil physical properties (e.g, soil water retention increase and soil evaporation decrease).

With the objective of improving irrigation efficiency in fruit orchards in the Ebro valley, Lordán et al. (2013) carried out an experiment using different methods of applying irrigation water, including, amongst others, deficit irrigation, the application of pressurized air and a rice husk amendment to subsurface irrigation. The results of tree growth after 2 years indicated a substantial effect of the rice husk amendment on soil physical properties (infiltration and hydraulic conductivity), which resulted in a higher canopy growth and trunk diameter. It seemed thus that soil amendment with rice husk substrate improved soil structure (Lordán et al., 2013).

A goal of this study is to understand the mechanisms that resulted in the improvements measured

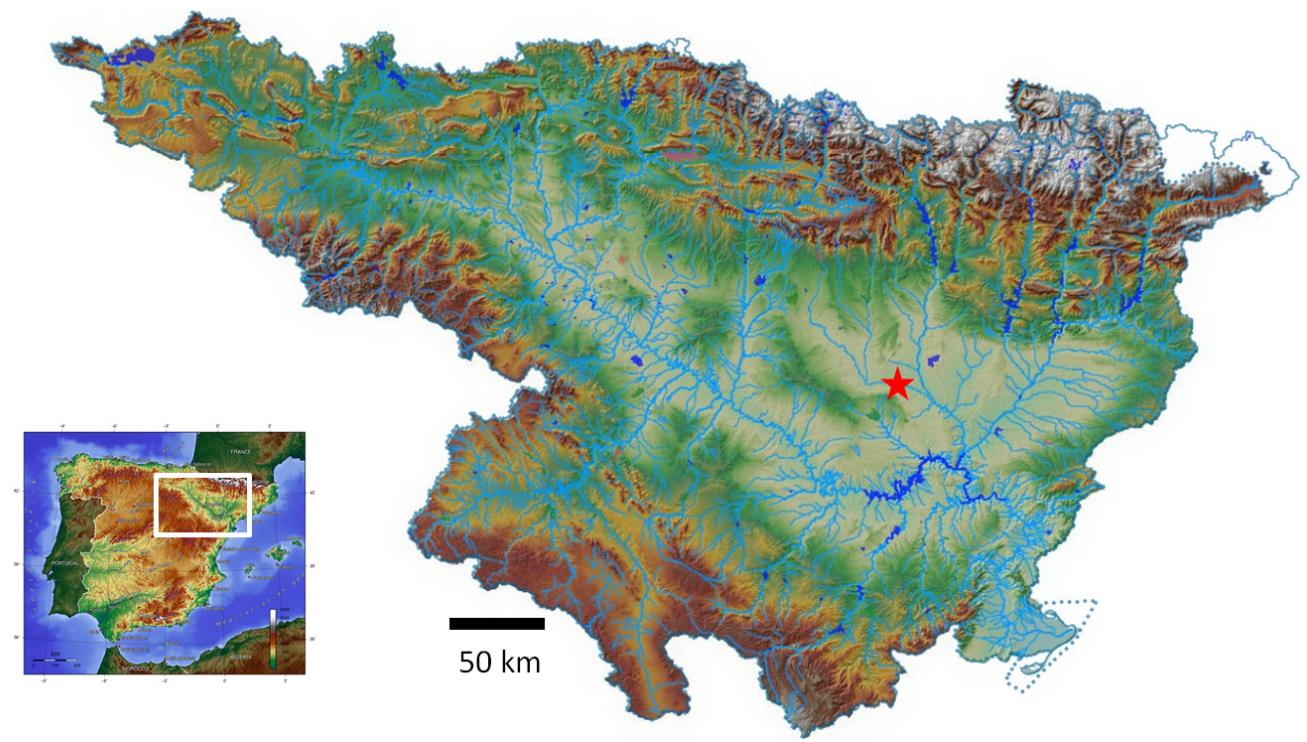

Figure 1 Location of the experimental site (red star, UTM-31 x:251.197, y:4.622.432) within the Ebro Valley. (Source: Confederación Hidrográfica del Ebro). 
RSDI 100

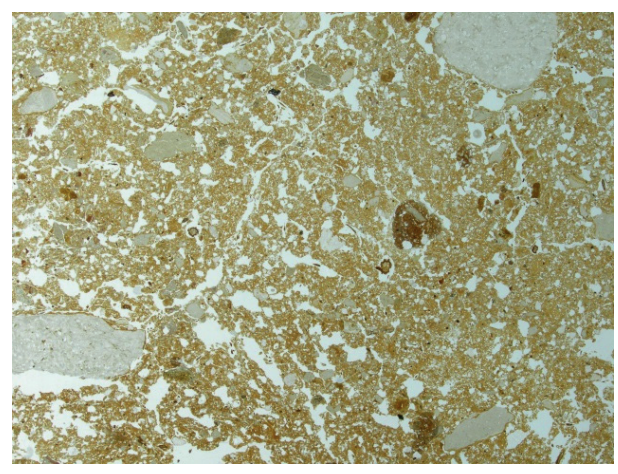

RSDI 70 air

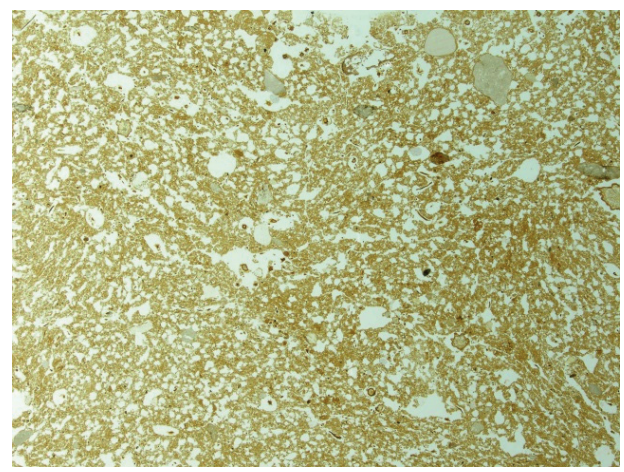

RSDI 70

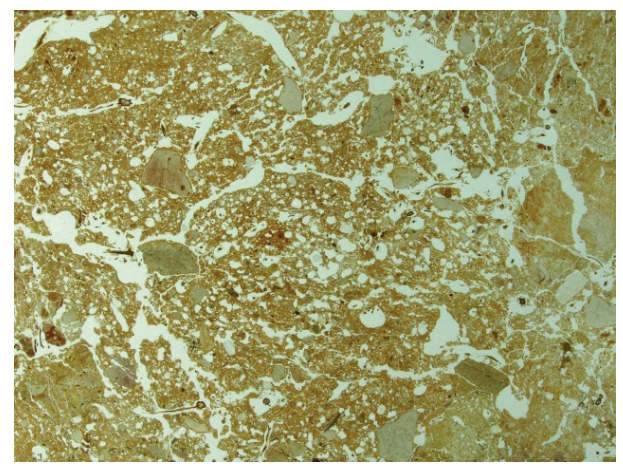

MR SDI 70

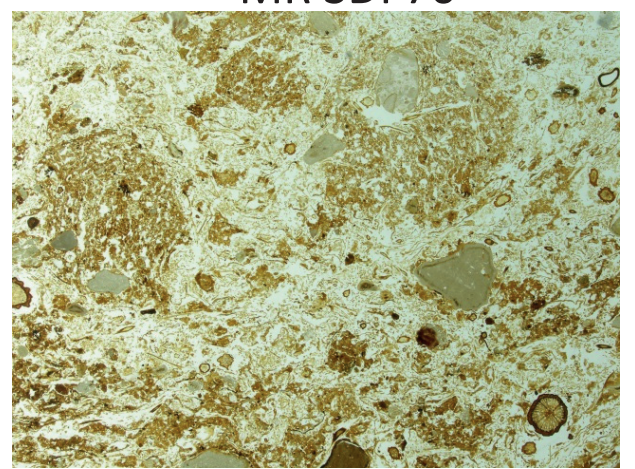

Figure 2 Scans of the four treatments. (1) RSDI 100: full irrigation. (2) RSDI 70: restricted irrigation (70\% water needs). (3) RSDI 70 air: same as (2) with pressurized air treatment in the pipes. (4) MR SDI 70: restricted irrigation with rice husk + gypsum. All images: planepolarized light; size: $3.15 \times 4.20 \mathrm{~cm}$.

by this experiment, by a detailed analysis of the porosity around the pipes using micromorphological and micromorphometrical approaches.

\section{Materials and methods}

\subsection{EXPERIMENTAL DESIGN AND TREATMENTS}

The experiments was carried out in a commercial peach orchard (Prunus persica L.) located in Villanueva de Sigena (Huesca, Spain) (Figure 1). The soil is a Xeric Torriorthent (Soil Survey Staff, 1999), developed from marls and with a silty-loam texture (USDA; $40 \%$ sand, $40 \%$ silt and 20\% clay). The soil is saline $\left(\mathrm{ECe}=6.0 \mathrm{dSm}^{-1}\right.$ at $\left.25^{\circ} \mathrm{C}\right)$, has a $\mathrm{pH}$ of 8.7 and an organic matter content of 10.0 $\mathrm{g} \mathrm{kg}^{-1}$. The trees were planted in 2010 at $5 \times 2.5$ $\mathrm{m}$, in a ridge planting system $(1.5 \mathrm{~m}$ bottom and
$0.8 \mathrm{~m}$ high), and irrigated through a subsurface irrigation system. The dripperline was buried at a depth of $0.25-0.3 \mathrm{~m}$ below the surface and was placed at a distance of $0.15-0.2 \mathrm{~m}$ from each tree trunk. Four different treatments of subsurface irrigation were tested:

(i) Full $(100 \%)$ ridge subsurface drip irrigation (RSDI 100).

(ii) Deficit ridge subsurface drip irrigation consisting of a $30 \%$ reduction ( $70 \%$ irrigation) in crop evapotranspiration through the season (RSDI 70).

(iii) Soil was mixed with rice husks and gypsum at respective proportions of 12:12:1 and placed around the irrigation pipes, prior to planting, at an application rate of $5.0 \mathrm{Mg} \mathrm{ha}^{-1}$ of rice husk (MR SDI 70). Irrigation was the same as described in item (ii).

(iv) Pressurized air injection and deficit subsurface irrigation as in (ii) (RSDI 70 air). 

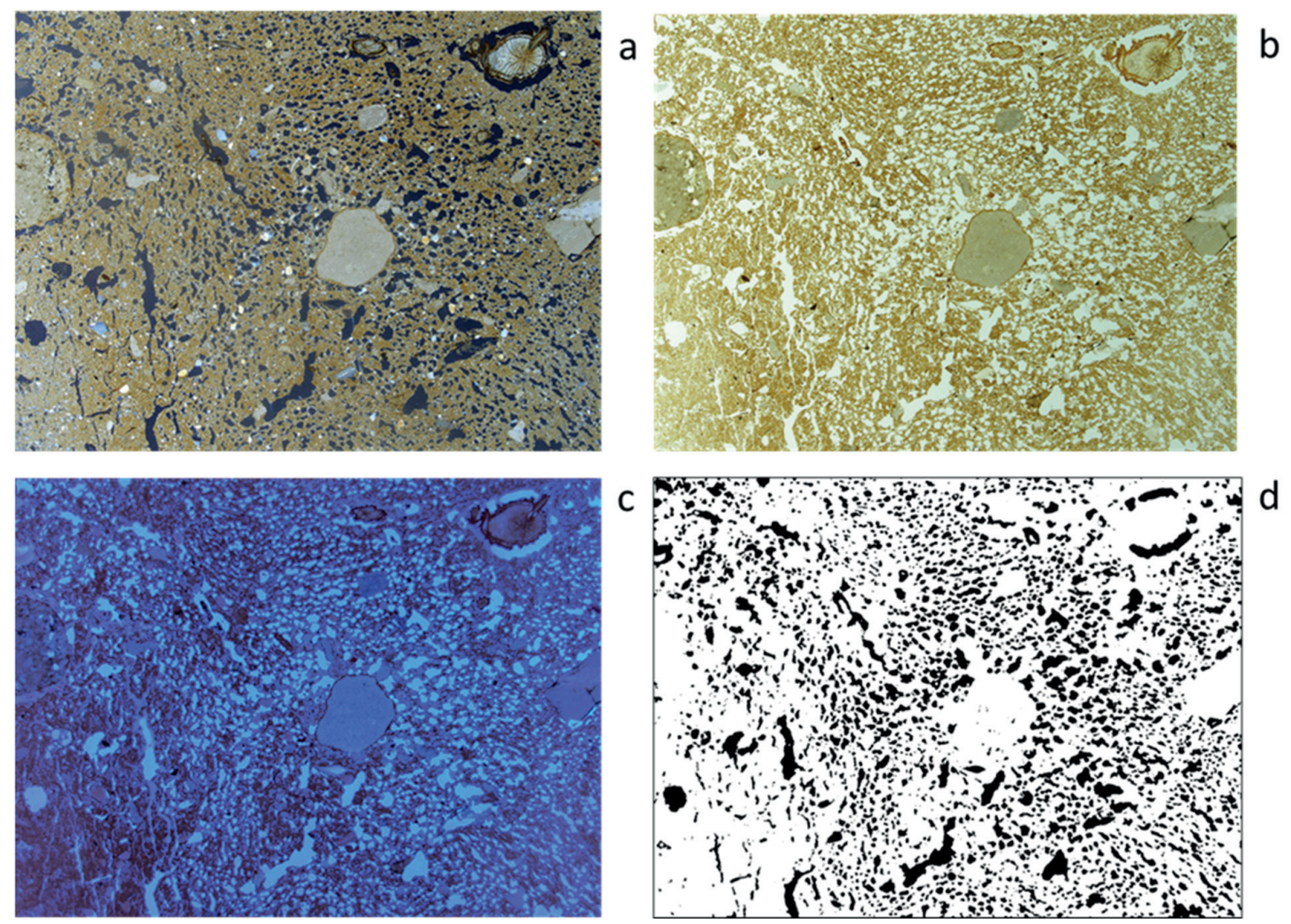

Figure 3 Images of one of the fields of the RSDI 70 air treatment. Note the vesicular pores. a) transmitted plane polarized light; b) transmitted crossed polarized light; c) reflected incident UV light; d) binarized image of the porosity (black) obtained from reflected incident UV light. Image size: $3.15 \mathrm{~cm}$ x $4.20 \mathrm{~cm}$.

A randomized complete block design with three replications was set up. Air injection was performed with a Venturi air injector (Mazzei Air Injector A3, Toro Ag, USA). The dripper line was buried between $0.25 \mathrm{~m}$ and $0.3 \mathrm{~m}$ below the surface and was at a distance of between $0.15 \mathrm{~m}$ and $0.2 \mathrm{~m}$ from each tree trunk. The complete soil and experiment design can be found in Lordán et al. (2013).

\subsection{ANALYSIS OF SOIL PROPERTIES}

In order to evaluate changes in soil physical properties, one undisturbed block ( $0.3 \mathrm{~m}$ each side) was taken from each treatment, and two vertical thin sections, $5 \times 13 \mathrm{~cm}$, including the subsurface pipe, were made following the methods of Benyarku and Stoops (2005). A fluorescent dye (Uvitex ${ }^{\circledR}$ ) was added to the polyester resin to obtain images of the porosity visible in UV light.

The description and study of the thin sections was done according to the guidelines of Stoops (2003). The thin sections were scanned in transmitted light. For the quantification of structure and porosity, three fields from each section, 13.23 $\mathrm{cm}^{2}$ each $(3.15 \mathrm{~cm} \times 4.20 \mathrm{~cm})$ were photographed in a light box to obtain transmitted-light images through the thin sections. Three different images were obtained for each of the 12 fields: (i) transmitted polarized light, (ii) transmitted light under crossed polarizers (using 2 perpendicularly oriented polarizing sheets, above and below the thin section), and (iii) incident UV light. The latter image was binarized using Image ${ }^{\circledR}$ (Rasband, 2014). The other two images were used as visual controls of the binarization quality of the porosity. 

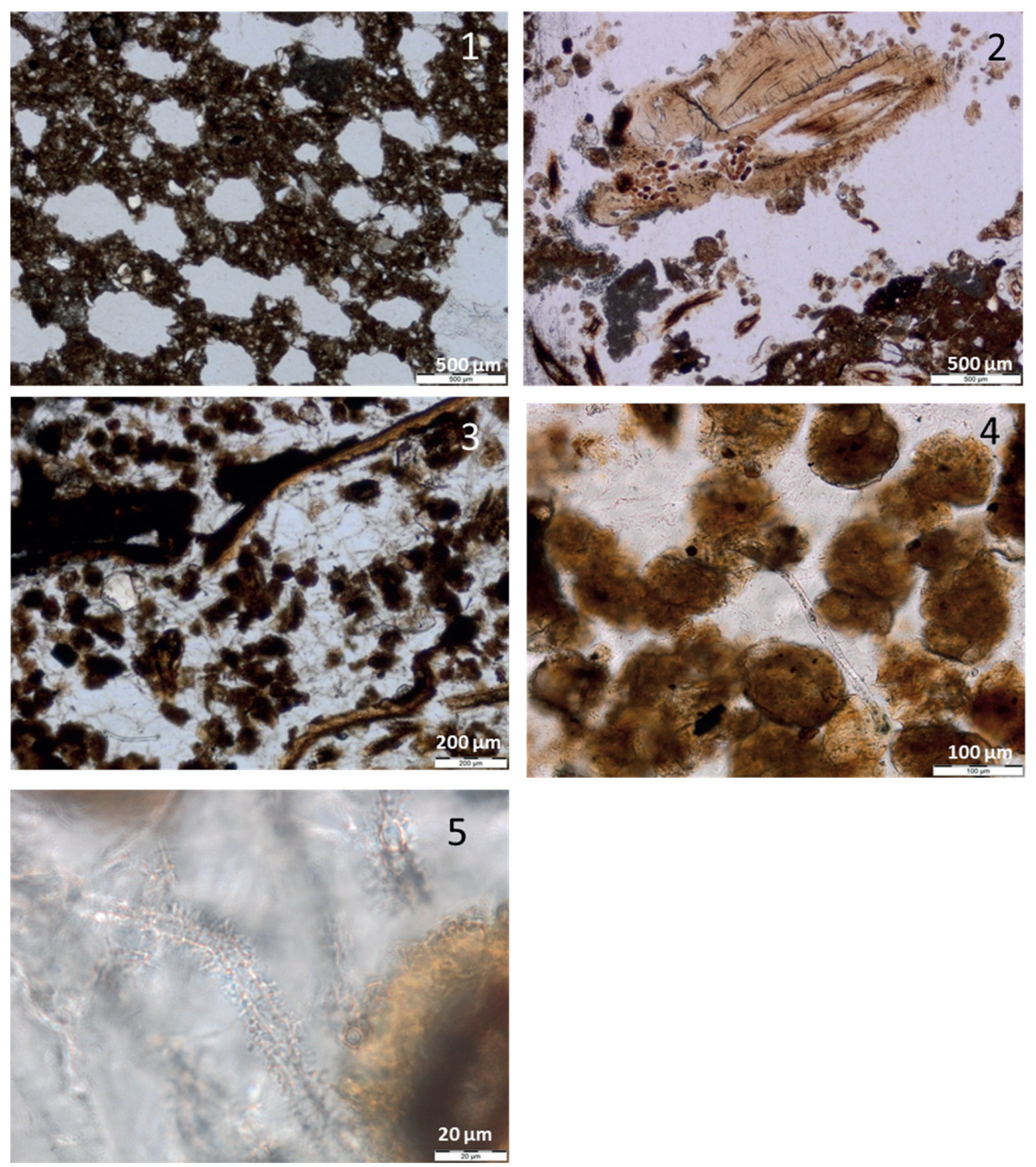

Figure 4 (1) Vesicular porosity of the RSDI 70 air treatment. (2) Oribatid excrements in plant residues. MR SDI 70 treatment. (3) Oribatid excrements, rice tissues and mesh of siliceous filaments in the pore system. MR SDI 70 treatment. (4) Detail of the Oribatid excrements. (5) Detail of the siliceous mesh. All images in plane-polarized light.

In all cases, the background noise (features below 1 pixel) was removed, which means that only the porosity larger than $15 \mu \mathrm{m}$ was visualized.

The pore parameters were analysed using the Image ${ }^{\circledR}$ software. The field parameters (a single value for each image) were total pore area and total pore perimeter, and were obtained from pore images including pore edges. The morphological parameters of each pore (excluding those pores cut by frame edges) were circularity (Equation 1) and solidity (Equation 2).

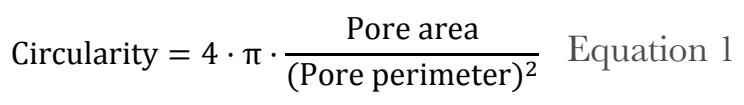

A circularity value of 1.0 indicates a perfect circle, while values close to 0.0 indicate elongated or irregular pores.

$$
\text { Solidity }=\frac{\text { Pore area }}{\text { Convex area }} \quad \text { Equation } 2
$$


Table 1. Average values of some morphological parameters of the pore system for the different treatments. Mean values in a row followed by different letters are significantly different at the 0.05 probability level based on the Tukey HSD test.

\begin{tabular}{|l|c|c|c|c|}
\hline & MR SDI 70 & RSDI 70 & RSDI 70 air & RSDI 100 \\
\hline Pore area fraction (\%) & $42.39 \mathrm{a}$ & $19.76 \mathrm{~b}$ & $25.32 \mathrm{~b}$ & $16.45 \mathrm{~b}$ \\
\hline Equivalent pore size (mm) & $0.28 \mathrm{a}$ & $0.14 \mathrm{~b}$ & $0.14 \mathrm{~b}$ & $0.11 \mathrm{~b}$ \\
\hline Average pore perimeter (mm) & $1.49 \mathrm{a}$ & $1.24 \mathrm{ab}$ & $1.31 \mathrm{ab}$ & $1.05 \mathrm{a}$ \\
\hline Specific perimeter $\left(\mathbf{m m}^{-\mathbf{1}}\right)$ & $2.33 \mathrm{a}$ & $1.70 \mathrm{~b}$ & $2.46 \mathrm{a}$ & $1.67 \mathrm{~b}$ \\
\hline Circularity (pore average)* & 0.764 & 0.768 & 0.757 & 0.775 \\
\hline Solidity (pore average)* & $0.832 \mathrm{~b}$ & $0.849 \mathrm{a}$ & $0.848 \mathrm{a}$ & $0.853 \mathrm{a}$ \\
\hline Number of replications & 9 & 6 & 8 & 6 \\
\hline
\end{tabular}

The convex area is the area included within the curve surrounding the pore (without concave segments). High values correspond to smooth pores, and low values to rough contours.

The pore size distribution was calculated using QuantIm4 (Vogel, 2008). The QuantIm4 program applied an opening algorithm to the pore space, overlaying circles of increasing diameters and discarding any pores that did not fill them. The images obtained were associated with different apparent pore diameter intervals. The percentage of (decreasing) porosity of each image was quantified. These apparent pore diameters are more meaningful for measuring soil porosity than equivalent pore diameters (diameter of a circle with the same area as the pore), as they can be assessed in terms of root penetration or water retention at a given matrix potential. Porosity ranges were set up according to different apparent pore diameter intervals: $15-30 \mu \mathrm{m}, 30-60 \mu \mathrm{m}, 60-100 \mu \mathrm{m}$, $100-200 \mu \mathrm{m}, 200-400 \mu \mathrm{m}$ and over $400 \mu \mathrm{m}$. Total porosity values accounted for all pores with equivalent diameter $>15 \mu \mathrm{m}$.

\subsection{DATA ANALYSIS}

A multivariate analysis of variance (MANOVA) model was used for analysis of soil average pore size, pore area fraction, average pore perimeter and specific perimeter, assuming colinearity between these variables. Later, links between significant variables and treatments were studied by multivariate discriminant analysis. The effects of treatments on tree growth and yield were determined using a linear mixed model (Type III sum of squares). The Tukey Honestly Significant Difference (THSD) post hoc test was used for comparing treatments and crop response data. All data analysis was performed using JMP-SAS software (JMP, Version 12 Pro. SAS Institute Inc., Cary, NC, 1989-2014).

\section{Results and discussion}

\subsection{MIGROMORPHOLOGY}

The groundmass of all thin sections is composed of a coarse fraction made of fine and medium sand of calcite and quartz, gravels of micritic limestone, and a micromass of clay, fine silt and micrite. The coarse/fine (c/f) ratio is approximately $1 / 2$ (c/f limit $20 \mu \mathrm{m}$ ) and the b-fabric is crystallitic micritic. Organic components are mainly root sections, and rice husks in the MR SDI 70 treatment.

\subsection{STRUCTURE AND POROSITY}

Noticeable changes in the pore types of the four treatments are evident in the scanned thin sections (Figure 2). The soils of the full and restricted irrigation treatments (RSDI 70 and 100) are characterised by a weakly developed, subangular blocky structure, with intra-aggregate vesicular pores, which are indicative of a poor structure. Some randomly oriented fragments of groundmass with 


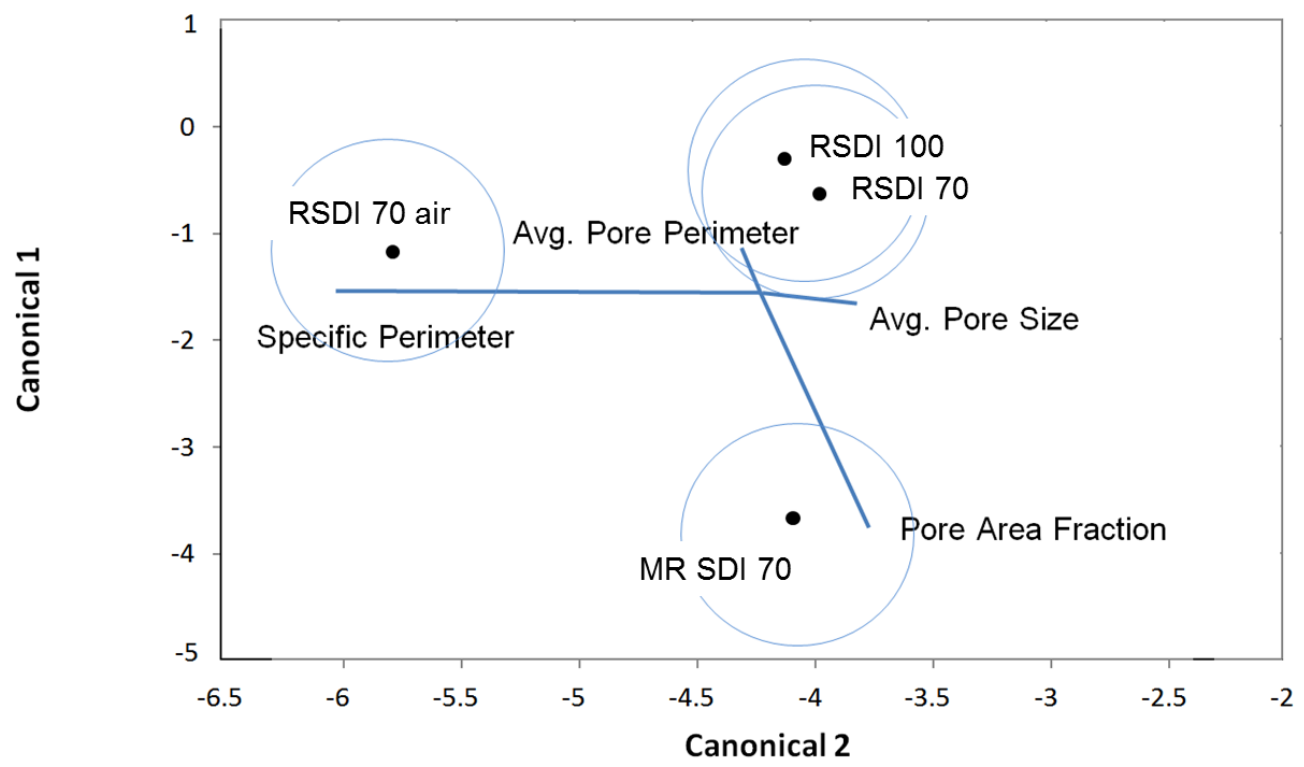

Figure 5 Biplot of the two first canonical components of the discriminant analysis. The model explains $86 \%$ of the total observed variability.

an internal laminar structure are present. These fragments are probably originated during the disturbance and packing of the soil materials when burying the pipe.

The restricted irrigation with pressurized air treatment (RSDI 70 air) produced, in its upper part, a soil structure similar to that of RSDI 70 and 100 . In the surroundings and below the pipe, where the effect of pressurized air was higher, the structure is apedal, with vesicles (bubbles) as main pores, with diameters of $100-400 \mu \mathrm{m}$ (figures 3 and 4.1).

The soil of restricted irrigation with rice husk treatment (MR SDI 70) has the highest porosity. Its micromorphology is characterized by the presence of many oval organic excrements, with sizes from 50 to $100 \mu \mathrm{m}$, associated with mildy decomposed rice husk tissues (Figures 4.2, 4.3, 4.4), in a very open fabric. The shape, size, organic nature and distribution of the excrements indicate that they are most probably produced by Oribatid mites (Zaiets and Poch, 2016, 2018). Mixed with the excrements it is possible to observe a mesh of siliceous threads that resemble silica skeletons of a freshwater sponge (Figures 4.3, 4.4, 4.5, Chad L. Yost, pers. comm.).

\subsection{MIGROMORPHOMETRY OF THE POROSITY}

Table 1 shows the results of the image analyses of the porosity. The pore area fraction confirms the visual estimations of the total pore area of the treatments. RSDI 100, RSDI 70, and RSDI 70 air have no significant differences with each other. MR SDI 70 has twice the pore area fraction as the other three. The equivalent pore size (in this case the diameter of a circular pore having the same area) follows the same trend.

The specific perimeter indicates the length of the interphase solid-void in the section, and corresponds to the surface of the same interphase related to the soil volume. It is higher in the treatments with air and with rice husks, but due to different processes: vesicles due to bubbling and biological activity. The physical behaviour is therefore different, since vesicles are non-connected pores and faunal activity creates highly connected 

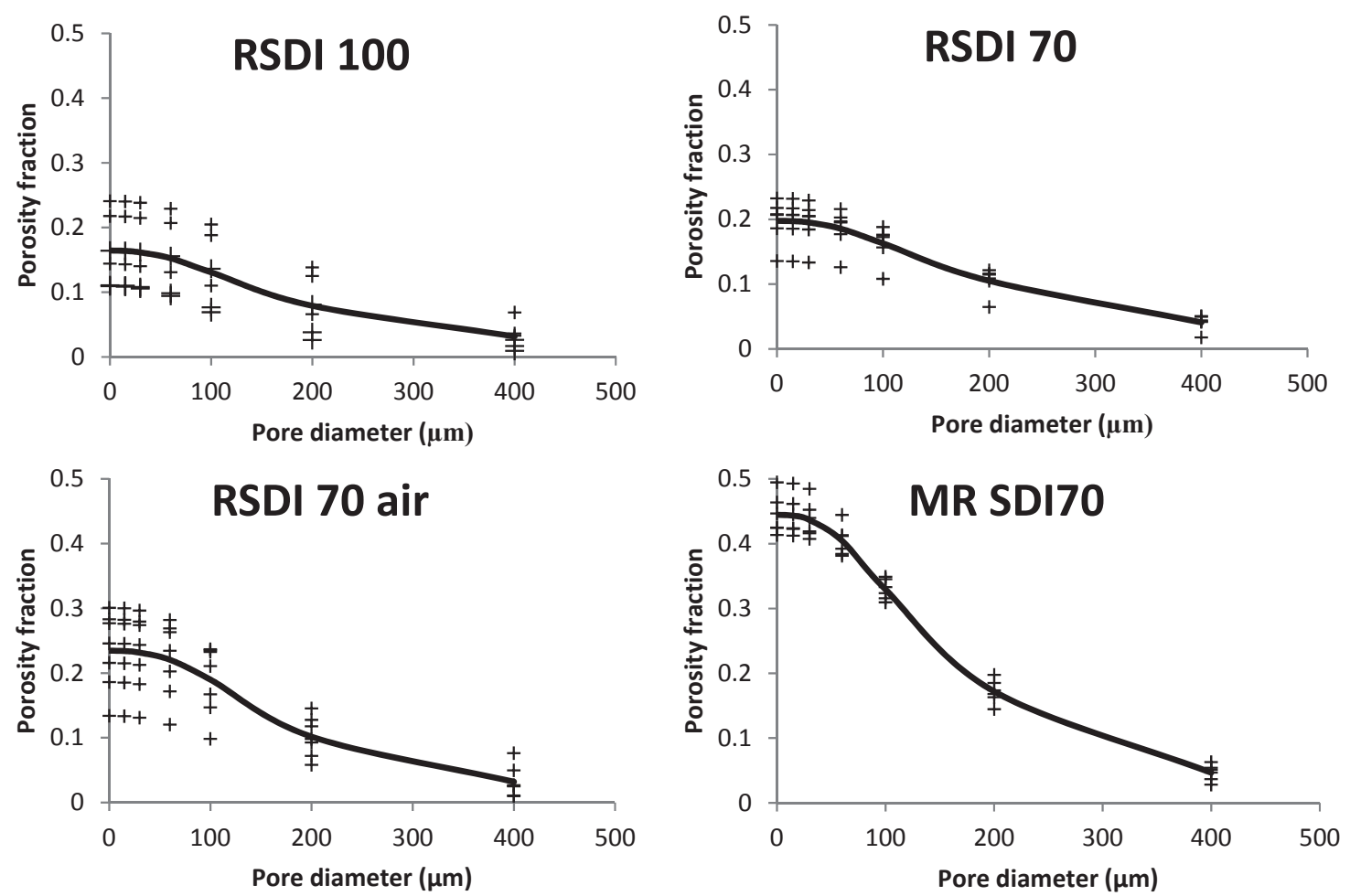

Figure 6 Pore size distributions. X-axis: pores larger than the given diameter in $\mu \mathrm{m}, \mathrm{Y}$-axis: total pore fraction.

pores. This high irregularity of the pores in the rice husk treatment (MR SDI70) is reflected in the lower solidity compared with the other treatments. No differences in pore circularity are observed.

The relation between these variables can be better seen with a MANOVA of the first four variables (Figure 5). The model is highly significant (Wilks' Lambda test $\mathrm{P}<0.0001 *$ ).

Figure 5 shows the centroid graph of the first two canonical components. They indicate that the porosity fraction is the main variable explaining differences between treatments, followed by the pore size.

The pore size distribution also differs depending on the treatment (Figure 6), with the MR SDI 70 (rice husk treatment) having higher porosities in all fractions, typically twice that of the other treatments (Table 2). The most different fraction is
$30-60 \mu \mathrm{m}$ (porosity fraction responsible for water retention), where the treatment with rice husk (MR SDI 70) triples the porosity compared to the other treatments. These porosity changes, due to faunal activity, explain the positive effects in the water retention capacity and also in the saturated hydraulic conductivity observed by Lordán et al. (2013), in comparison to pressurized air that only increases vesicular (non-connected) porosity.

Oribatid richness and diversity have been related to soil structure (Ducarme et al., 2004; Jorrín and González-Fernández, 2016) and to soil organic matter (Noti et al., 2003) among other factors, but without establishing any clear cause-effect relationship. Our micromorphological study shows that rice husk packing, together with the mite activity feeding on them, are responsible for the high packing porosity. 
Table 2. Percentages of pore diameter classes in the studied images. Mean values in a row followed by different letters are significantly different at the 0.05 probability level based on the Tukey HSD test.

\begin{tabular}{|c|c|c|c|c|}
\hline $\begin{array}{c}\text { Diameter } \\
(\boldsymbol{\mu m})\end{array}$ & MR SDI 70 & RSDI 70 & RSDI 70 air & RSDI 100 \\
\hline $\mathbf{0 - 1 5}$ & $0.14 \mathrm{a}$ & $0.05 \mathrm{~b}$ & $0.06 \mathrm{~b}$ & $0.07 \mathrm{~b}$ \\
\hline $\mathbf{1 5 - 3 0}$ & $0.67 \mathrm{a}$ & $0.21 \mathrm{~b}$ & $0.24 \mathrm{~b}$ & $0.24 \mathrm{~b}$ \\
\hline $\mathbf{3 0 - 6 0}$ & $3.20 \mathrm{a}$ & $0.95 \mathrm{~b}$ & $1.10 \mathrm{~b}$ & $0.89 \mathrm{~b}$ \\
\hline $\mathbf{6 0 - 1 0 0}$ & $7.52 \mathrm{a}$ & $2.28 \mathrm{~b}$ & $3.07 \mathrm{~b}$ & $2.17 \mathrm{~b}$ \\
\hline $\mathbf{1 0 0 - 2 0 0}$ & $15.73 \mathrm{a}$ & $5.78 \mathrm{bc}$ & $8.82 \mathrm{~b}$ & $5.17 \mathrm{c}$ \\
\hline $\mathbf{2 0 0 - 4 0 0}$ & $12.54 \mathrm{a}$ & $6.41 \mathrm{~b}$ & $6.97 \mathrm{~b}$ & $4.74 \mathrm{~b}$ \\
\hline $\begin{array}{c}\text { Number of } \\
\text { replications }\end{array}$ & 6 & 6 & 7 & 6 \\
\hline
\end{tabular}

\section{Conclusions}

The improvement of physical properties of a soil amended with rice husk, translated to a higher canopy cover and tree growth in peach orchards with subsurface irrigation in the Ebro Valley, is caused by the activity of mites (probably Oribatid) feeding on these organic residues. This treatment, even with restricted irrigation, modifies the soil structure by doubling the soil porosity and reducing pore smoothness compared to the full irrigation, restricted irrigation and pressurized air with restricted irrigation treatments. These porosity changes imply higher water retention and a higher efficiency conveying water to the roots. In all the treatments, the nature of the material (intentionally altered soil around the pipes) is responsible for the absence of pedofeatures, other than those with faunal origin. Our results stress the importance of promoting the biological activity of micro and mesofauna in all management practices tending to increase the irrigation efficiency in poorly structured soils.

\section{Acknowledgements}

This research was financed by project grant RTA2009-00056-00-00 from Spain's Ministry of
Economy and Competitiveness. We are grateful to Dr Michele Francis (U. Stellenbosch) for her useful comments and language revision.

\section{References}

Benyarku, C.A., Stoops, G., 2005, Guidelines for preparation of rock and soil thin sections and polished sections: Lleida, Spain, Departament de Medi Ambient i Ciències del Sòl, Universitat de Lleida, Quaderns DMACS, 33, 84 p.

Diana, G., Beni, C., Marconi, S., 2008, Organic and mineral fertilization: effects on physical characteristics and boron dynamic in an agricultural soil: Communications in Soil Science and Plant Analysis, 39(9-10), 1332-1351.

Ducarme, X., André, H.M., Wauthy, G., Lebrun, P., 2004, Are there real endogeic species in temperate forest mites?: Pedobiologia, 48(2), 139-147.

Jorrín, J., González-Fernández, P., 2016, Plantconservative agriculture of acid and degraded Raña-grassland enhances diversity of the common soil mites (Oribatida): Spanish Journal of Agricultural Research, 14(1), e0302. 
Kar, G., Kumar, A., 2007, Effects of irrigation and straw mulch on water use and tuber yield of potato in eastern India: Agricultural Water Management, 94(1-3), 109-116.

Kumar, S., Malik, R.S., Dahiya, I.S., 1985, Influence of different organic wastes upon water retention, transmission and contact characteristics of a sandy soil: Australian Journal of Soil Research, 23(2), 131-136.

Lordán, J., Pascual, M., Fonseca, F., Villar, J.M., Rufat, J., 2013, Use of rice husk to enhance peach tree performance in soils with limiting physical properties: Soil and Tillage Research, 129, 19-22.

Mubarak, A.R., Ragab, O.E., Ali, A.A., Hamed, N.E., 2009, Short-term studies on use of organic amendments for amelioration of a sandy soil: African Journal of Agricultural Research, 4(7), 621-627.

Noti, M.I., André, H.M., Ducarme, X., Lebrun, P., 2003, Diversity of soil oribatid mites (Acari: Oribatida) from High Katanga (Democratic Republic of Congo): a multiscale and multifactor approach. Biodiversity and Conservation, 12(4), 767-785.

Nwite, J.N., Mbah, C.N., Okonkwo, C.I., Me, O., 2011, Analysis of the physical conditions of a contaminated typic haplustult amended with organic wastes: International Research
Journal of Agricultural Science and Soil Science, 1(2), 58-63.

Rasband, W.S., 2014, ImageJ 1997-2012: Bethesda, U.S.A., U.S. National Institutes of Health, retrieved October, 2018, from http://imagej.net/index.html.

Soil Survey Staff, 1999, Soil Taxonomy, a Basic System of Soil Classification for Making and Interpreting Soil Surveys: Washington, D.C., U.S.A., United States Department of Agriculture, Natural Resources Conservation Service, Agriculture Handbook 436, 869 p.

Stoops, G., 2003, Guidelines for analysis and description of soil and regolith thin sections: Madison, U.S.A., Soil Science Society of America, $184 \mathrm{p}$.

Vogel, H.J., 2008. QuantIm4 C/C++ Library for scientific image processing. Version 4.01 20.10.2008: Helmhotz, Germany, UFZ - Helmholtz Center for Environmental Research, 49 p.

Zaiets, O., Poch, R.M., 2016, Micromorphology of organic matter and humus in Mediterranean mountain soils: Geoderma, 272, 83-92.

Zaiets, O., Poch, R.M., 2018, Use of micromorphology for humus characterization and classification in some mediterranean calcareous soils: Applied Soil Ecology, 123, 672-681. 